\title{
In vitro detection of hepatitis C virus in platelets from uninfected individuals exposed to the virus
}

\section{Juliana Lara Padovani ${ }^{[1]}$, Silvia Maria Corvino ${ }^{[1]}$, Jan Felix Drexler ${ }^{[2]}$, Giovanni Faria Silva ${ }^{[3]}$, Maria Inês de Moura Campos Pardini ${ }^{[1],[3]}$ and Rejane Maria Tommasini Grotto ${ }^{[1]}$}

[1]. Laboratório de Biologia Molecular do Hemocentro de Botucatu, Faculdade de Medicina de Botucatu, Universidade Estadual Paulista -UNESP, Botucatu, SP. Brasil.

[2]. Laboratório de Pesquisa em Doenças Infecciosas, Hospital Universitário Prof. Edgard Santos, Universidade Federal da Bahia. Salvador, BA, Brasil.

[3]. Departamento de Clínica Médica, Faculdade de Medicina de Botucatu, Universidade Estadual Paulista - UNESP, Botucatu, SP, Brasil.

\begin{abstract}
Introduction: Despite hepatocytes being the target cells of hepatitis C virus (HCV), viral ribonucleic acid RNA has been detected in other cells, including platelets, which have been described as carriers of the virus in the circulation of infected patients. Platelets do not express cluster differentiation $81 \mathrm{CD} 81$, the main receptor for the virus in hepatocytes, although this receptor protein has been found in megakaryocytes. Still, it is not clear if HCV interacts with platelets directly or if this interaction is a consequence of its association with megakaryocytes. The aim of this study was to evaluate the interaction of $\mathrm{HCV}$ with platelets from non-infected individuals, after in vitro exposure to the virus. Methods: Platelets obtained from 50 blood donors not infected by $\mathrm{HCV}$ were incubated in vitro at $37^{\circ} \mathrm{C}$ for $48 \mathrm{~h}$ with serum containing $100,000 \mathrm{IU} / \mathrm{mL}$ of genotype $1 \mathrm{HCV}$. After incubation, RNA extracted from the platelets was assayed for the presence of HCV by reverse transcription - polymerase chain reaction RT-PCR. Results: After incubation in the presence of virus, all samples of platelets showed HCV RNA. Conclusions: The results demonstrate that, in vitro, the virus interacts with platelets despite the absence of the receptor CD81, suggesting that other molecules could be involved in this association.
\end{abstract}

Keywords: HCV. Platelets. CD81.

\section{INTRODUCTION}

Hepatitis $\mathrm{C}$ virus (HCV) infects approximately 170 million people in all the world, where it is one of the principal causes of chronic hepatitis, cirrhosis and hepatocarcinom ${ }^{1-3}$.

Hepatocytes constitute the principal target cells of the virus ${ }^{4,5}$ and express cluster differentiation $81 \mathrm{CD} 81$, the main receptor associated with the entrance of $\mathrm{HCV}^{6,7}$. However, studies have demonstrated the presence of viral ribonucleic acid RNA in other cell types ${ }^{4}$, including platelets ${ }^{8,9}$. In addition, platelets have been shown to act as carriers of the virus in the circulation of individuals infected by the virus ${ }^{10}$. However, platelets do not express CD81, although the presence of this receptor has been described in megakaryocytes ${ }^{11}$.

Still, little is known about the interaction HCV and platelets. It is not known if this process occurs initially in the megakaryocyte, where the virus is consequently transferred to the platelets or if the platelets can interact directly with $\mathrm{HCV}$, even though not expressing CD81.

Address to: Dra. Maria Inês de Moura Campos Pardini. Lab. Biologia Molecular do Hemocentro/FMB/UNESP. Distrito de Rubião Jr s/n, 18618-000 Botucatu, SP, Brasil.

Phone: 5514 3811-6041; Ramal: 205; Fax: 5514 3811-6041

e-mail: regrotto@uol.com.br

Received 10 May 2012

Accepted 16 January 2013
Thus, the aim of this study was evaluate in vitro the possible interaction of $\mathrm{HCV}$ with platelets from non-infected blood donors.

\section{METHODS}

Aliquots of ethylenediaminetetraacetic acid EDTAanticoagulated peripheral venous blood were collected from 50 donors at the Botucatu Medical School's Blood Transfusion Center. Inclusion criteria were: serology negative for anti-HCV antibody, absence of RNA-HCV confirmed by molecular assays and signed informed consent.

The blood sample was centrifuged for $3 \mathrm{~min}$ at $1,312 \mathrm{xg}$ for plasma separation. The plasma was then centrifuged for $5 \mathrm{~min}$ at $1,600 \mathrm{xg}$ to pellet the platelets. The supernatant was removed and the platelet pellet was washed with $0.9 \% \mathrm{NaCl}$ five times. At this step, platelet pellet aliquots were separated and used to prepare slides for Leishman staining.

The platelet pellet was incubated with $1 \mathrm{~mL}$ of serum pool containing $100,000 \mathrm{IU} / \mathrm{mL}$ of genotype $1 \mathrm{HCV}$. The incubation was at $37^{\circ} \mathrm{C}$ in an Incubator Shaker (New Brunswick Scientific, USA) for $48 \mathrm{~h}$ with horizontal mixing at $30 \mathrm{xg}$.

After incubation, the samples were washed with $0.9 \%$ $\mathrm{NaCl}$ five times, and the last supernatant was used for $\mathrm{HCV}$ amplification for reverse transcription - polymerase chain reaction (RT-PCR), to assure the absence of HCV serum.

The platelet pellet was isolated using Buffer RLT (QIAGEN, Valencia, CA, USA) followed by the QIAamp Viral RNA Mini 
kit (QIAGEN, Valencia, CA, USA) protocol and was used as the source for HCV 5'UTR genomic region amplification by RT-PCR ${ }^{12,13}$. To evaluate the quantification of HCV-RNA in platelets the RNA was used as source for real time PCR according methodology described by Dexter et al. ${ }^{14}$.

Two negative controls were used in the procedure: one with the platelet pellet incubated with pooled HCV seronegative serum and the other consisting of an empty tube incubated with the same serum pool used in test samples, without platelets.

\section{Ethical considerations}

The study was approved by the Research Ethics Committee of Botucatu School of Medicine (number 3134-2009), Universidade Estadual Paulista (UNESP).

\section{RESULTS}

The 50 blood donors included in this study had a mean age of 33.5 years, (interquartile range, $24.5-42.7)$, where $13(26 \%)$ were men and $37(74 \%)$ women.

All samples gave a result of not detectable for the presence of the viral RNA of HCV before incubation with the virus.

After incubation with HCV-RNA positive serum, the presence of HCV RNA was detected in all platelet samples, evidenced by the amplification of the 5'UTR region, but when RT-PCR was used 32 (64\%) samples presented HCV-RNA upper 18.4UI/mL. All negative controls utilized showed undetectable RT-PCR, validating the experiment.

\section{DISCUSSION}

The platelets have been described as carriers of $\mathrm{HCV}$ in infected patients ${ }^{8}$, despite that these cells do not express CD81, the principal receptor utilized by the virus for entrance into hepatocytes ${ }^{6}$. However, previous studies have demonstrated the presence of mRNA coding for CD81 in megakaryocytes ${ }^{12}$, and expression of the receptor protein as well ${ }^{11}$. Still, little is known about the direct interaction of $\mathrm{HCV}$ with platelets.

The results obtained here showed that in $100 \%$ of the platelets tested, HCV RNA was detected after incubation with serum containing viral RNA, suggesting that the virus-platelet interaction does not require the megakaryocyte as the initial step of the process.

In addiction others molecules can be suggest how candidates in interaction $\mathrm{HCV}$-platelets as fibronectin ${ }^{10}$ or others adhesion molecules ${ }^{15}$. Further studies are needed for a better understanding of these interactions.

\section{ACKNOWLEDGMENTS}

To volunteer donors for their participation in the study.

\section{CONFLICT OF INTEREST}

The authors declare that there is no conflict of interest.

\section{REFERENCES}

1. World Health Organization (WHO). Media Center - Hepatitis C. [Internet] WHO; 2011. [Cited 2011 August 18] Available from: http://www.who.int/ mediacentre/factsheets/fs164/en/index.html/.

2. Davis GL, Albright JE, Cook SF, Rosenberg DM. Projecting future complications of chronic hepatitis C in the United States. Liver Transpl 2003; 9:331-338.

3. Revie D, Salahuddin SZ. Human cell types important for Hepatitis C Virus replication in vivo and in vitro. Old assertions and current evidence. Virol $\mathrm{J}$ $2011 ; 8: 346$.

4. Reynolds GM, Harris HJ, Jennings A, Hu K, Grove J, Lalor PF, et al. Hepatitis $\mathrm{C}$ virus receptor expression in normal and diseased liver tissue. Hepatol $2008 ; 47: 418-427$.

5. Oliveira GSS, Nicodemo AC, Carvalho VC, Zambrini H, Siqueira AM, Amato AS. Severe hepatitis and jaundice during the evolution of dengue virus infection: case report. Rev Soc Bras Med Trop 2010; 43 (suppl III):339-341.

6. Farquhar MJ, Harris HJ, McKeating JA. Hepatitis C virus entry and the tetraspanin CD81. Biochem Soc Trans 2011; 39:532-536.

7. Molina S, Castet V, Garcia PL, Wychowski C, Meurs EJ, Pascussi JM, et al. Serum-Derived Hepatitis C Virus Infection of Primary Human Hepatocytes Is Tetraspanin CD81 Dependent. J Virol 2008; 82:569-574.

8. Hamaia S, Li C, Allain JP. The dynamics of hepatitis $\mathrm{C}$ virus binding to platelets and 2 mononuclear cell lines. Blood 2001; 98:2293-2300.

9. Almeida AJ, Campos-de-Magalhães M, Melo-Marçal OP, Brandão-Mello CE, Okawa MY, Oliveira RV, et al. Hepatitis C virus-associated thrombocytopenia: a controlled prospective, Virological Study Ann Hematol 2004; 83:434-440.

10. Pugliese A, Gennero L, Cutufia M, Enrietto ME, Morra E, Pescarmona P, et al. $\mathrm{HCV}$ infective virions can be carried by human platelets. Cell Biochem Funct 2004; 22:353-358.

11. Ma F, Wada M, Yoshino H, Ebihara Y, Ishii T, Manabe A, et al. Development of human lymphohematopoietic stem and progenitor cells defined by expression of CD34 and CD81. Blood 2001; 97:3755-3762.

12. Garson JA, Ring C, Tuke P, Tedder RS. Enhanced detection by PCR of hepatitis C vírus RNA. The Lancet 1990; 336:878-879.

13. Sawada L, Pinheiro ACC, Locks D, Pimenta ASC, Rezende PR, Crespo DM. Distribution of hepatitis $\mathrm{C}$ virus genotypes among different exposure categories in the State of Pará, Brazilian Amazon. Rev Soc Bras Med Trop 2011; 44 (supl 1I):8-12.

14. Drexler JF, Kupfer B, Petersen N, Grotto RMT, Rodrigues SMC, Grywna K, et al. A novel diagnostic target in the hepatitis $\mathrm{C}$ virus genome. PLoS Med 2009; 6:2-11.

15. Tanaka M, Kamijo T, Koike K, Ueno I, Nakazawa Y, Kurokawa Y, et al. Specific autoantibodies to platelet glycoproteins in Epstein-Barr virus-associated immune thrombocytopenia. Int J Hematol 2003; 78:168-170. 